\title{
TUTURAN EMOSI MAHASISWA KOTA BAU BAU
}

\section{Tim PSP2M and Risman Iye}

\author{
Universitas Iqra Buru
}

Bahasa yang dihasilkan oleh seseorang akan selalu menjadi cerminan pribadi, derajat sikap, watak atau karakter mental spiritualnya. Oleh karena itu, bahasa dipandang sebagai identitas yang nyata bagi penutur-penuturnya. Kata atau bahasa yang digunakan oleh seseorang dalam berturtur disebut dengan istilah pragmatik. Levinson dalam Tarigan (1990)[1], bahasa mempunyai peranan penting dalam kehidupan manusia. Selain sebagai media komunikasi, bahasa juga dapat digunakan seseorang untuk mengekspresikan dirinya dan segala hal yang dirasakan untuk diungkapkan kepada orang lain. Menurut Chaer (2012), dengan bahasa memungkinkan tiap orang untuk mempelajari kebiasaan, adat istiadat, kebudayaan, serta latar belakang antarpeserta komunikasi masing-masing[2][3]. Melalui bahasa pula, seseorang dapat mengungkapkan emosinya, baik emosi positif maupun emosi negatif. Salah satu hal yang berhubungan dengan pengungkapan emosi negatif, yaitu makian.

Kata-kata makian sering ditemukan dalam demontrasi karena mahasiwa cenderung menggunakan bahasa yang kasar dan tidak ditutup-tutupi. Salah satu bentuk pemakaian tuturan emosi ini banyak ditemukan di Kota Baubau.Misalnya tuturan para demonstran, yaitu selamat malamKota Baubau.Kata ini apabila diucapkan saat malam hari tentu tidak dikatakan sebagai emosi karena diucapkan sesuai dengan keadaan sebenarnya namun apabila kata tersebut diucapkan siang hari dengan mimik merah dan suara lantang tentu memiliki makna lain bahkan bisa dikatakan sebagai emosi[4]. Contoh lain juga pada kata bantingarti kata banting pada bidangnya tentu terasa biasa. Kalau orang sedang membicarakan soal-soal ekonomi, tentu artinya adalah memurahkan harga, dan apabila diucapkan oleh pemain judo tentulah banting berarti mengangkat seseorang dan menjatuhkan dengan cepat[5]. Jadi dapat dikatakan bahwa dalam ilmu prgmatik pemakain bahasa terikat dengan konteks.

Sebagai makhluk hidup, manusia tentunya tidak lepas dari emosi, baik emosi positif maupun emosi negatif. Menurut Goleman [6], emosi merujuk pada suatu perasaan dan pikiran- pikiran khasnya, suatu keadaan biologis dan psikologis serta serangkaian kecenderungan untuk bertindak. Emosi positif adalah ungkapan jiwa seseorang untuk menyatakan perasaan senang atau gembira. Sebaliknya, emosi negatif adalah ungkapan jiwa seseorang untuk menyatakan perasaan sakit hati, marah, kecewa, sedih, terkejut, kesal, dan sebagainya yang dapat diungkapkan melalui bahasa. Hal ini dipertegas pula oleh Khodijah (2006) bahwa emosi negatif didasari oleh terhalangnya keinginan, sehingga bisa menyebabkan frustasi. Dalam menyampaikan maksudnya atau mengungkapkan emosinya itu, manusia menggunakan bahasa yang berbeda-beda.

Pemakaian tuturan emosi tidak terlepas dari beberapa hal yang memengaruhinya yaitu latar atau suasana. Keterkaitan penggunaan bahasa dengan konteks (situasi tutur) yang menyertai bahasa tersebut merupakan salah satu hal yang menarik dalam kajian pragmatik menurut Baskoro (2014)[7], pragmatik mengkaji struktur bahasa secara eksternal, yakni bagaimana satuan kebahasaan digunakan di dalam berkomunikasi. Penggunaan bahasa dalam percakapan sehari-hari kadang-kadang mengandung makna yang berbeda dalam konteks yang berbeda pula. Dengan kata lain, arti dari sebuah kata harus disesuaikan dengan konteks kalimatnya. Yule (2014)[8], menjelaskan pragmatik adalah studi tentang makna yang disampaikan oleh penutur (penulis) dan ditafsirkan oleh pendengar (pembaca) pendengar berusaha menafsirkan tuturan penutur sehingga akan diperoleh makna, maksud, tujuan dari penutur. Setelah pendengar mengetahui maksud penutur maka akan diketahui jenis tindakan yang harus dilakukan oleh pendengar. Untuk itu yang menjadi pusat perhatian pragmatik adalah maksud penutur yang terdapat dibalik tuturan yang diutarakan[9].

Seiring perkembangan waktu dalam dunia mahasiswa seringkali kita temukan beragam kebiasaan yang tidak terlepas, yaitu demonstrasi yang mana kegiatan ini merupakan aksi menyampaikan aspirasi di tempat umum dengan maksud dan tujuan menyuarakan segala 
macam kebijakan- kebijakan yang diambil oleh pemegang otoritas (pemimpin atau penguasa) yang tidak prorakyat. Dalam menyampaiakan aspirasinya orang yang berdemostrasi memakai bahasa sebagai perantara dengan wujud formal hal ini didukung pula pendapat Rahardi (2005), wujud tuturan adalah jenis atau ragam tuturan yang digunakan seorang penutur dalam menyampaikan pesan kepada mitra tutur[10]. Di setiap negara demokrasi termasuk Indonesia segala bentuk aspirasi rakyat bisa disampaiakan secara bebas dan terbuka. Menurut Savero (2008), demonstrasi adalah tindakan untuk menyampaikan penolakan[11][12], kritik, ketidakberpihakan, mengajari hal-hal yang dianggap sebuah penyimpangan. Terlepas dari semua itu seringkali peserta demonstrasi dalam menyampaikan aspirasinya cenderung menggunakan tuturan emosi dalam isi penyampaiannya[13]. Dalam setiap tuturan terlihat penggunaan piranti linguistik yang mewujudkan suatu tuturan,termasuk tuturan emosi dalam ranah demonstrasi. Bentuk tuturan emosi dalam ranah demonstrasi dapat berwujud kata, frasa, kalimat, maupun ungkapan yang di dalamnya disesuaikan dengan jenis tuturan emosi yang terungkapkan.

\section{DAFTAR PUSTAKA}

[1] M. C. B. Umanailo, "Eksistensi Waranggana Dalam Ritual Tayub,” 2017.

[2] M. C. B. Umanailo and T. Yatno, Kajian dan Analisis Sosiologi Dalam Bentuk Kumpulan Essay, Makalah dan Opini. 2015.

[3] M. C. B. Umanailo, "Pierre Bourdieu; Menyikap Kuasa Simbol," in OSF, 2014.

[4] M. C. B. Umanailo, "Desa Sebagai Poros Pembangunan Daerah," 2015.

[5] M. C. B. Umanailo, "Adakah Ukuran Kemiskinan Buat Masyarakat Di Kabupaten Buru?," 2017.

[6] M. C. B. Umanailo, MASYARAKAT BURU DALAM PERSPEKTIF KONTEMPORER (Kajian Kritis Perubahan Sosial di Kabupaten Buru). 2015.

[7] M. C. B. Umanailo, "Mengurai Kemiskinan Di Kabupaten Buru," 2017.

[8] M. C. B. Umanailo, ILMU SOSIAL BUDAYA DASAR, 1st ed. Namlea: FAM PUBLISHING, 2015.

[9] M. C. B. Umanailo, "Studi pada Masyarakat Desa Waimangit Kabupaten Buru," SOCA, vol. 12, no. 12, pp. 63-74, 2018.

[10] M. C. B. Umanailo, "PENCIPTAAN SUMBERDAYA MANUSIA YANG BERKARAKTER.” 2017.

[11] M. C. B. Umanailo, Sosiologi Hukum, 1st ed. Namlea: FAM PUBLISHING, 2016.

[12] M. C. B. Umanailo, "MEREDUKSI MULTI PARTAI UNTUK KESTABILAN PEMBANGUNAN NASIONAL." 2017.

[13] M. C. B. Umanailo, "Keterbatasan penggunaan teknologi informasi pada pelayanan dan pembelajaran di universitas iqra buru," 2016. 